FRANS J. SCHRYER is a member of the Department of Sociology and Anthropology at the University of Guelph.

This case study of the 'ranchero' region of Sierra Alta de Hidalgo offers a new perspective on the rancheros and their role in the Mexican Revolution and its aftermath. Focusing on the economic and political history of the municipio of Pisaflores over the past hundred years, the author demonstrates that the rancheros were not subsistence family farmers, as they have been described by other scholars, but commercial farmers, a local élite employing wage labourers.

This 'peasant bourgeoisie' far outnumbered the absentee owners of huge haciendas who figure so prominently in the literature, and they played an important part in the armed phase of the Mexican Revolution that started in 1910. The Revolution, in fact, provided individual members of this rural class with a unique opportunity to improve their economic and social position. In the Sierra Alta de Hidalgo many rancheros became local revolutionaries, recruiting their own employees and tenants, and two members of prominent ranchero families eventually became governors of central states.

A detailed political history of Pisaflores between 1920 and 1970 shows how the rancheros responded to the larger economic changes in twentiethcentury Mexico. The author suggests that the political behaviour of the peasant bourgeoisie was a logical outcome of the pattern of land tenure and its corresponding class structure. The book as a whole provides new insights into the operation of the de facto one-part: system of Mexico, the use of an agrarian ideology, the operation of land reform, and the changing network of links between local, regional, and national politicians in this remote but not insignificant rural region. 

FRANS J. SCHRYER

\section{The Rancheros of Pisaflores: The History of a Peasant Bourgeoisie in Twentieth-Century Mexico}

UNIVERSITY OF TORONTO PRESS Toronto Buffalo London 
(C) University of Toronto Press 1980

Toronto Buffalo London

Printed in Canada

Reprinted in 2018

Library of Congress Cataloging in Publication Data

Schryer, Frans J

The rancheros of Pisaflores.

Bibliography: p.

I. Peasantry - Mexico - Pisaflores region (Veracruz)

- History. 2. Pisaflores region, Mexico (Veracruz) -

Rural conditions. 3. Political participation-Mexico

- Pisaflores region (Veracruz) - History. I. Title.

HD330.P57S37 30I.44'43'09726 79-20686

ISBN 0-8020-5466-8

ISBN 978-1-4875-8089-6 (paper)

All photographs are from the author's collection. 


\section{To the memories of}

FRANS JOHAN SCHRYER

soldier and craftsman

and

JOZEF MACOVICH

merchant and anti-cleric 
